\title{
The International Association on the Genesis of Ore Deposits (IAGOD)
}

\author{
http://www.geology.cz/host/iagod.htm
}

Research into the origin of ore deposits lies at the cornerstone of many sub-disciplines in the geological sciences. The number of methods that can be successfully applied to understand the processes involved in the generation, localization and preservation of economic concentrations of ore minerals continues to grow. High levels of expertise in mineralogy, petrology, geochemistry and structural geology are increasingly needed by those who wish to understand ores. Whatever part of the world one lives in, the economic importance of mineral exploitation is evident, even though dramatic structural changes in the mining industry have occurred in the past two decades, leaving large parts of the industrialized world without a significant domestic metal mining industry, despite ever growing consumer demand. Although focus may have changed substantially in recent years as a consequence of political actions, including appreciably more research on the environmental effects of mining, ore deposit research has never been more important, as the search for new, undiscovered ore deposits becomes more difficult and costly. Despite the lack of focus on ore geology in some universities, the central role of ore geology is just as evident today, in the 3rd millennium A.D., as it was in the past. With this, and ever-increasing globalization in mind, good possibilities for international collaboration are more important than ever before to all scientists whose goal is to understand how and why ore deposits are formed.

The International Association on the Genesis of Ore Deposits (IAGOD) promotes cooperation in the study of the genesis of ore deposits. IAGOD is an international association with both individual and national group members across the globe. For nearly 40 years now, the association has aimed at facilitating international exchange among scientists, with special emphasis on nurturing scientific collaboration with countries in Eastern Europe, the Commonwealth of Independent States, China, and the developing world. IAGOD is particularly well represented in countries with a significant knowledge base and still traditional values in educational programs, and in which ore mining and exploration are mainstays of the economy

\section{Association history}

The 'Provisional Commission on the Genesis of Ore Deposits' originated at the international symposium on "Problems of Post-magmatic Ore Deposition with Special Reference to the Geochemistry of Ore Veins" held in Prague in September 1963. The IAGOD was formally established one year later during the IGC in New Delhi, India, with the aim of fostering collaboration between Eastern and Western ore geologists, as had been achieved in Prague. In 1966, IAGOD became a member of the International Union of Geological Sciences.

The association holds a major scientific conference every four years (Table).

$\begin{array}{lll}1963 & \text { Prague } & \text { Czechoslovakia } \\ 1967 & \text { St. Andrews } & \text { Scotland } \\ 1971 & \text { Tokyo } & \text { Japan } \\ 1974 & \text { Varna } & \text { Bulgaria } \\ 1978 & \text { Snowbird, Utah } & \text { USA } \\ 1982 & \text { Tblisi, Georgia } & \text { USSR } \\ 1986 & \text { LuleÂ } & \text { Sweden } \\ 1990 & \text { Ottawa } & \text { Canada } \\ 1994 & \text { Beijing } & \text { P.R China } \\ 1999 & \text { London* } & \text { United Kingdom } \\ 2002 & \text { Windhoek** }^{* *} & \text { Namibia }\end{array}$

\section{Membership}

Current membership stands at more than 750 scientists from 68 countries. These include individual members and also members organized within 12 'national' IAGOD groups (China, Czech Republic, Georgia, Kazakhstan, Kyrgyzstan, Mongolia, Russia, Slovak Republic, Spain, Tajikistan, Ukraine and Uzbekistan). IAGOD welcomes the establishment of new 'national' groups.

IAGOD members pay a nominal $\$ 10$ in annual dues, with the national groups paying a lump sum $(\$ 50-\$ 500)$, depending on group size. IAGOD is therefore an affordable association for many, even in economically disadvantaged countries. A dozen corporations, including multinational mining companies, choose institutional membership (\$100 annually). The remainder of IAGOD financing comes from publication sales, from IUGS (who kindly support dues for the most disadvantaged national groups) and, occasionally, profits from scientific meetings.

Membership of the association is open to all scientists interested in genetic problems of ores. Inquiries concerning membership (including national groups and institutional membership) should be addressed to: Dr. R. Seltmann, IAGOD Membership Secretary, Natural History Museum, Dept. Mineralogy, Cromwell Road, London SW7 5BD, United Kingdom, e-mail:rs@ @nhm.ac.uk

IAGOD membership facilitates participation in an international association focusing on ore deposit studies, including events organized or co-sponsored by IAGOD, reduced registration fees for IAGOD symposia, workshops and meetings, receipt of the annual IAGOD Newsletter, availability of IAGOD publications at reduced prices, and participation in the activities of the IAGOD commissions and working groups. IAGOD welcomes new members, including those who would like to serve in commissions and working groups, to give their energy and ideas to meet the many exciting challenges that face 'our' science today.

\section{Council and scientific organization}

The council of IAGOD has 19 members: President, Past-president, Honorary past-president, two Vice-presidents, two Vice-presidentsat-large, Secretary General and Associate Secretary General, Membership Secretary, Chief Treasurer, 6 Regional Representatives (one each for Europe, North America, South America, Africa, Asia and Southwest Pacific) and two ex-officio representatives from the Society for Geology Applied to Ore Deposits (SGA).

IAGOD members are involved on aspects of research on all types of ore deposits, and at all scales from intercontinental GIS studies down to nanoscale ore mineralogy. Scientific activities of IAGOD are carried out within commissions and working groups (Table). Sug-

Commission on Paragenesis

$\mathrm{PaC}$

Commission on Ore-Forming Fluids in Inclusions

COFFI

Commission on Industrial Minerals and Rocks

COIMR

Commission on Ore Deposits in Mafic \& Ultramafic Rocks

Commission on Thermodynamics of Ore Forming Fluids

Commission on Placer Deposits

CODMUR

Commission on Tectonics of Ore Deposits

COPD

- WG on Global Tectonics \& Metallogeny

- WG on Tectono-Magmatic Activization

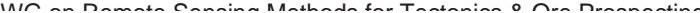

CTOD

DIWA 
gestions for additional commissions or working groups are always welcome.

IAGOD groups have a long tradition of proposing, leading and working within various IGCP projects. Current or recently completed IGCP projects with significant IAGOD involvement include IGCP 354 (Economic Super-accumulation of Metals in Lithosphere), 373 (Correlation, Anatomy and Magmatic-Hydrothermal Evolution of Ore-Bearing Felsic Igneous Systems in Eurasia), 427 (Ore-Forming Processes in Dynamic Magmatic Systems), 429 (Organics in Major Environmental Issues), 443 (Magnesite and Talc-Geological and Environmental Correlations). IAGOD council members are also the lead scientists in project $\mathbf{4 7 3}$ (GIS Metallogeny of Central Asia) and the recently approved IGCP project 486 'Au-Ag-telluride-selenide deposits'. The writers own personal experience with initiation of the latter project has demonstrated the pivotal role that associations like IAGOD can play in the preparation of successful IGCP project applications. IAGOD members, and the commissions and working groups, also participate in collaborative projects with other international bodies and programs in the field of ore deposit research.

\section{Recent and forthcoming congresses and meetings}

The most recent Quadrennial IAGOD Symposium (the 11th) attracted nearly 500 participants from all over the world, who enjoyed an excellent five-day scientific program and six excursions to some of the finest ore deposit geology anywhere. The next Quadrennial IAGOD meeting will be held in Saint Petersburg, Russia in 2006.

IAGOD, or its national groups or commissions, also organize or co-sponsor numerous smaller-scale meetings, workshops and excursions. For example, The IAGOD National Group of the Czech Republic organized the successful thematic meeting 'Uranium Deposits; from their Genesis to their Environmental Aspects' in Prague, September 10-11th 2002.

During 2003, IAGOD is involved in two field conferences: 'Geodynamics and Metallogeny of Mongolia', organized by the Mongolian IAGOD group, July 30th-August 7th; and 'Paleozoic Geodynamic Processes and Metallogeny of Chinese Altay and Tianshan', the IGCP-473 Field Symposium in Urumqi, China, August 9th-21st, organised by the Chinese IAGOD group, with excursion to Chinese Tienshan and Altay (Xinjiang). The Uzbekistan IAGOD group are organizing the Ore Deposits Exploration Symposium 'Uzbekistan Gold - 2003' in Tashkent, with excursions, 21st-24th October 2003.

Next year, an interim IAGOD conference 'Metallogeny of the Pacific Northwest: Tectonics, Magmatism and Metallogeny of Active Continental Margins", organized by the 'Far East' chapter of the IAGOD Russian group. The meeting will be held in Vladivostok, Russian Far East, between September 11th and 19th 2004, with an exciting program of field trips to ore deposits across the region on offer to delegates.

In addition, IAGOD, or constituent commissions, convenes or organizes sessions at other geological conferences. Several sessions and symposia took place under the IAGOD 'flag' at the IGC in Rio de Janeiro in 2000, and IAGOD will also be present at the 32nd IGC in Florence in 2004. IAGOD also works closely with both the Society of Economic Geologists (SEG) and the Society for Geology Applied to Ore Deposits (SGA) in organizing or co-sponsoring meetings, and also involves itself in the co-sponsorship of other regular congresses, such as in the 15th ECROFI meeting in Portugal in 2001.

Some of our most successful scientific conferences and field workshops in recent years have arisen from the close collaboration of national and working groups. The Working Group on Tin and Tungsten deposits, for example, co-organized the IGCP-373 Field Conference in the Urals "The Eroded Urals Paleozoic Ocean to Continent Transition Zone: Granitoids and Related Ore Deposits", held

\section{Publications}

The main organ of the IAGOD has traditionally been the annual IAGOD Newsletter 2002, containing reports from the national groups and commissions, details of recent and forthcoming meetings, and occasional short articles and abstracts of interest.

IAGOD's publication series is well established among ore geologists and continues to expand with additional titles appearing most years. The range of IAGOD monographs includes Ore-Bearing Granites of Russia and Adjacent Countries (Kremenetsky et al., 2000). The IAGOD map series also continues to grow in size. Recent additions include Gold mineralization map of the Southern Urals, Scale 1:1,000,000 (Shatov et al.) and Mineral Deposits map of Central Asia, Scale 1:1,500,000 (Seltmann et al.). These are available both in printed and digital format on CD. IAGOD Excursion Guidebooks are a further, popular range of publications, as they contain descriptions of ore deposits that are unavailable elsewhere. Recent additions include: $\mathrm{Au}, \mathrm{Ag}$, and $\mathrm{Cu}$ Deposits of Uzbekistan-Excursion Guidebook, International Field Conference of IGCP-373 and Excursion B6 of the Joint SGA-IAGOD Symposium, London/Tashkent: 27th August-4th September 1999; Granitoids and Related Ore Deposits of the Urals, Excursion Guidebook (2000), and Paleozoic Geodynamics and Gold Deposits in the Kyrgyz Tien Shan (2001). Several new additions to the IAGOD Guidebook series, including those for events to be held during 2003, are currently in preparation.

A major new event for IAGOD is the decision to adopt, from mid-2003, to adopt the journal Ore Geology Reviews, published by Elsevier, as the official scientific journal of the association. IAGOD council has long recognized the need to be involved, editorially, in a high-quality scientific journal that can publish articles of interest to IAGOD members and substantially raise the profile of the association within the geoscientific community at large. It is also an exciting challenge to the new editorial team, to be led by the undersigned, and largely drawn from the ranks of IAGOD members on all continents. We intend to use the journal to publish high-quality articles and special issues, which deal with topics close to the goals of IAGOD. In particular, we plan to publish descriptive papers that deal with newly discovered or genetically enigmatic deposits, as well as papers that, based on good science, seek to provoke discussion on contentious issue. It is planned that the digital version of the journal can be disseminated to IAGOD membership worldwide.

The journal Global Tectonics and Metallogeny, published by Schweizerbart'sche and edited by Jan Kutina, is part of the activities of the Commission on Tectonics of Ore Deposits (CTOD), and works closely with IAGOD. CTOD also publishes a number of abstract and proceedings volumes. The IAGOD working group on Ores \& Metamorphism (WGOM) publishes an annual newsletter for distribution to its 150 members. Other IAGOD publications include two volumes of the book Ore Deposits of Continental Margins, published by the Russian Far East IAGOD Group.

\section{Find out more and join today!}

IAGOD is an active association with much on offer to all scientists with an interest, direct or indirect, in ore deposits. We have plans, enthusiasm and creative energy and intend to continue to play a leading role in collaboration among ore geologists worldwide, and in particular as an agency that can help assist the sustainable development, to borrow a phrase, of ore geologists across the world on a strictly non-profit basis without economic prejudice.

To find out more, consult the association website at http://www.geology.cz/host/iagod.htm, or contact the writer. Better still, join IAGOD and discover the benefits of membership!

Nigel Cook
Secretary General IAGOD 